\title{
Compliance with IFRS 7 by financial institutions: Evidence from GCC
}

\author{
Amal Yamani \\ University of Portsmouth \\ Khaled Hussainey \\ University of Portsmouth
}

\begin{abstract}
The purpose of this paper is to address the essential steps for constructing a compliance index. It answers the research question: 'What are the guidelines for constructing the compliance index with IFRS 7?' To conduct this study, an index is constructed based on the disclosure requirements of financial instruments (i.e. IFRS 7). The sample includes listed banks from the GCC countries that adopted IFRS mandatorily from 2011 to 2017. Further, a descriptive analysis is employed. The findings emphasise the significant role of the steps outlined in constructing the index. Despite the importance of all the steps mentioned (basic source, materiality, reliability, validity, and scoring), there are some forms that can be considered as alternatives for each other. Overall, clarifying these steps for constructing an index will no doubt increase the effectiveness of the tool used for measuring the compliance level. Consequently, future researchers can concentrate more on other types of requirement, such as measurement and presentation. They may also include non-financial sectors and give more attention to the other scoring methods mentioned in the study.

The study contributes to the IASB by supporting their efforts towards improving disclosure, especially in mandatory cases. It also supports all initiatives and efforts of policy makers, government institutions, and formal associations. The study presents illustrative steps to establish an index under the basic requirements (narrative study). Moreover, it provides a new index to measure cross-country compliance with IFRS 7.
\end{abstract}

Keywords: compliance, disclosure, international financial reporting standards, IFRS 7, index, GCC. 


\section{Compliance with IFRS 7 by financial institutions: Evidence from GCC}

\subsection{Introduction}

The emergence of international financial reporting standards (IFRS) and their adoption by many countries has shown to be one of the most important challenges affecting global accounting harmonisation: i.e., the proper application of these standards as required. More clearly, this issue revolves around compliance with the application of the standards, which may vary from one country to another due to the different infrastructure of each country as well as other aspects (Baazaoui, 2019; Black, 2012). For that, many researchers have measured the degree of compliance with the standards in order to enhance accounting harmonisation and help to achieve the desired objectives, such as understanding of the standards and comparability between countries. To do so, the most common instrument used by researchers to measure compliance levels is the index (Tsalavoutas, Tsoligkas, \& Evans, 2018; Urquiza, Navarro, \& Trombetta, 2010).

Due to the increasing challenges of the IFRS, it became important to focus on all the components of financial reporting such as financial statements, notes, and information related to the different ratios and financial instruments - which is probably the most significant one. As defined by Lim and Foo (2017, p.49), a financial instrument is "a contract that gives rise to a financial asset of one entity and a financial liability or equity instrument of another entity". Financial instruments have been discussed extensively over many years by the International Accounting Standards Board (IASB). After different stages of updates and processes, the mandatory application of the IFRS 7 was enforced in 2007. IFRS 7 standards contain all the requirements that should be included in the financial statements related to the financial instruments' disclosures, as well as all the risks arising from the implementation of financial instruments (Deloitte, 2017a, 2017b, 2017d, 2017e).

In addition, financial disclosure is considered one of the most important elements of the financial reporting process in particular, and to the firms' life in general. Accounting researchers even point to financial disclosure as the business language that can facilitate financial communication between all stakeholders (Palmieri, Perrin, \& Whitehouse, 2018). Gibbins, Richardson and Waterhouse (1990, p.196, cited in Crawford Camiciottoli, 2013) are perhaps the first researchers to introduce a definition of financial disclosure as: "any deliberate public release of financial information, whether voluntary or required, numbers or words, formal or informal, at any time during the year". This disclosed information may comprise financial (quantitative) and nonfinancial (qualitative) information. Different parties have a certain role in this circle of financial disclosure process, such as accountants, management, auditors, and analysts. In addition, the means of introducing financial disclosure may take different forms: periodic bulletins, official websites, analysts' research, or through the most common type which is corporate annual reports.

In light of the above, the importance of the compliance issue highlights the need to focus on the instrument used to measure the compliance (index) to achieve the desired results and, in turn, to 
reduce the differences in application of standards across countries. In addition, in focusing on the disclosure requirements related to one of the most important components of financial reports financial instruments - the researcher addresses this compliance tool in detail in this study by stating the following question: what are the steps (guidelines) for constructing the compliance index with IFRS 7?

The motivations for this study are centred on several points: (1) the study discusses the required steps for constructing an index, which is considered a 'map' for informing future researchers looking to construct an index; (2) the study outlines the different methods used in literature for scoring the index, and then concentrates on the most appropriate for the current research to apply (Cooke's formula); and (3) in response to calls by prior studies (Hassan \& Marston, 2018; Tsalavoutas et al., 2018), this study highlights the role of three aspects - materiality, validation, and reliability - in constructing an index, which are essential components.

It has been found empirically that every step (basic source, materiality, reliability, validity, and scoring techniques) mentioned as a part of constructing the compliance index plays a significant role. However, there are some forms that can be considered alternatives for one another, as will be explained later. Overall, clarifying these steps for constructing an index and discussing them in detail will no doubt increase the effectiveness of the compliance tool used for measuring the compliance level. The two main issues discussed in the literature regarding disclosure indices were the items selection for the index, and the scoring formula employed for measuring the index. Prior literature did not show clear, accurate bases that can be followed to select the applicable disclosure items for a disclosure index (Alanezi \& Albuloushi, 2011; Alanezi, Alfaraih, Alrashaid, \& Albolushi, 2012; Demir \& Bahadir, 2014). They also did not consider different methods for the index, and the main focus was only on Cooke's formula (Tsalavoutas et al., 2018).

Furthermore, Tsalavoutas et al. (2018) and Hassan and Marston (2018) stress the importance of validity and reliability due to their impact on the robustness of the research methodology. They also point to the existing gaps related to these aspects in compliance studies. Therefore, this study contributes to the knowledge by filling the gaps in literature related to measuring compliance levels, especially with regard to financial instruments. It provides a clear map and guiding principles for future researchers who intend to adopt the index method for various research purposes. It also gives an extensive discussion about validity, reliability, materiality and scoring, and what role they may play in enhancing the compliance instrument and reducing the contradictions found in previous findings.

In addition, this study provides a methodological contribution by constructing a new compliance index to measure the mandatory disclosure requirements of the International Financial Reporting Standards related to financial instruments (IFRS 7). It will shed light on the significant parts of this standard, and the significance of the financial instruments. This index will be applied to a group of developing countries from the Gulf Cooperation Council (GCC), and this consequently will provide new empirical evidence of the disclosure practices in GCC countries. Moreover, the 
study contributes to the IASB by supporting their efforts towards improving disclosure, especially with mandatory requirements. From another side, the study supports all initiatives and efforts of policy makers, state legislators, government institutions, formal associations, and corporate governance, which are responsible for monitoring organisations' performance - especially now, since the adoption of IFRS has become mandatory in most countries of the world.

Hence, the originality and novelty of this study lies in presenting illustrative descriptive steps in order to establish an index under the basic requirements (narrative study). In addition, the researcher applies these steps practically on a specific single aspect of the IFRS which is Financial Instruments: Disclosures (IFRS 7). The outcomes of this study are centred on presenting a disclosure index with items covered by the selected standard and scoring (Cooke's method) that index for a sample of listed banks from the GCC countries from 2011 until 2017.

The remainder of this study is organised as follows. The next section reviews literature related to compliance levels, including the methods (proxies) of compliance measurements employed in previous studies and discusses the existing gaps. Following that, section three highlights the research design adopted for this study, including the sample and the suggested guideline. Section four demonstrates the significant results of the study, and finally, a summary of the key outcomes of the study is provided in section five.

\subsection{Literature review}

\subsubsection{Financial reporting quality: Compliance}

Literature regarding IFRS compliance showed mixed results (Agyei-Mensah, 2019; Alfraih \& Almutawa, 2017; Allini, Ferri, Maffei, \& Zampella, 2019; Al Mutawaa \& Hewaidy, 2010; AlShammari, 2011; Ballas, Sykianakis, Tzovas, \& Vassilakopoulos, 2018; Bova \& Pereira, 2012; Demir \& Bahadir, 2014; Ebrahim \& Abdel Fattah, 2015; Fekete, Matis, \& Lukács, 2008; Halbouni \& Yasin, 2016; Hla et al., 2013; Tauringana \& Chithambo, 2016; Tsalavoutas, 2011), which led many researchers to investigate these contradictory findings by conducting more studies in the area.

The reality shows that the quality of financial accounting is influenced obviously by the quality of financial disclosure, which in turn affects the assessment of companies, the decision-making process, and the efficiency of capital markets (Pivac, Vuko, \& Cular, 2017). Consequently, and after global developments in the business environment (especially after adopting the IFRS), researchers have increased their interest in measuring disclosure levels by focusing on the compliance issue $^{1}$ (Abdul Rahman \& Hamdan, 2017; Al-Akra, Eddie, \& Ali, 2010; Alfaraih, 2009;

\footnotetext{
${ }^{1}$ There is a distinction between the degree of compliance and the degree of disclosure. The degree of compliance
} includes all possible compliance elements that are under consideration, for example measurement requirements, 
Alfraih \& Almutawa, 2017; Al Mutawaa \& Hewaidy, 2010; Al-Shammari, 2011; Ebrahim \& Abdel Fattah, 2015; Hla, Hassan, \& Shaikh, 2013; Juhmani, 2017). They also have attempted to determine the impact of the compliance with IFRS mandatory/voluntary disclosure on various aspects such as economic and social factors and the performance of capital markets.

Accordingly, the disclosure was classified into two main categories: mandatory disclosure and voluntary disclosure. Mandatory disclosure, which is the focus of this study, refers to the financial/non-financial information or items that must be disclosed based on legal obligations such as IFRS. However, voluntary disclosure encompasses all the information that an entity wishes to disclose, for example the transparency and strength of its position within an increasingly competitive environment. This information is not considered binding or required by certain rules or accounting standards (Al-Shammari, 2005; Elshandidy, Fraser, \& Hussainey, 2015; Gutierrez Ponce, Hlaciuc, Mates, \& Maciuca, 2016; Li \& Yang, 2016).

Previous studies state that there is considerable controversy among academics based on the concept of financial reporting quality. Bamber (2011) explains that the quality of financial reporting implies qualitative characteristics, such as relevance, understandability and comparability. The difficulty of constructing a measure based on this dimension means that some research failed to overcome this obstacle (Jonas \& Blanchet, 2000; Lee, Walker, Christensen, \& Zhao, 2010). Therefore, researchers have relied on the principle that capturing the qualitative characteristics can be achieved through surveying and interviewing individuals. Moreover, they consider compliance as one of the financial reporting quality proxies, particularly as it is related with disclosure requirements (Bamber, 2011). From a critical view, compliance cannot reflect the whole quality of financial reporting, since it represents only a part, or one side, of the financial reporting. However, due to the difficulty of measuring qualitative characteristics, most researchers have adopted disclosure as one of the more appropriate tools to measure compliance somewhat satisfactorily. Therefore, it can be seen that financial disclosure builds a bridge for providing the information directly between business enterprises on the one hand, and all relevant parties from outside the company on the other (Achim \& Chis, 2014; Ahmed, 2012; Crawford Camiciottoli, 2013).

\subsubsection{Proxies for measuring compliance level}

The difficult nature of measuring disclosure and its quality leads to considerable debate between researchers about what the most appropriate method is for measuring disclosure levels; that is, disclosure is sometimes based on an intangible stand which is not directly captured (Hassan \& Marston, 2018; Ibrahim \& Hussainey, 2019; Urquiza et al., 2010; von Alberti-Alhtaybat, Hutaibat, \& Al-Htaybat, 2012). This is demonstrated by the study of Hassan and Marston (2018), who reviewed 280 studies on disclosure and found that prior studies used different methods as a proxy

presentation requirements, etc. This is in contrast to the degree of disclosure, which focuses only on disclosure requirements. In this study, the two terms will be used as an alternative to each other. 
of disclosure. These methods varied between disclosure count (to measure disclosure quantity), properties of reported earnings (to measure the quality of disclosure), and disclosure index (to measure the quantity/quality of disclosure). In addition, other methods such as classification approach, sentiment analysis, market-based variables and adopting high-quality standards are used to measure different dimensions of financial disclosure (Hassan \& Marston, 2018). However, measuring compliance levels by employing an index was the most common method in previous literature (Agyei-Mensah, 2019; Bravo Urquiza, Abad Navarro, \& Trombetta, 2009; Coy \& Dixon, 2004; Hossain, 2002; Tsalavoutas et al., 2018). IFRS compliance literature relies on constructing/developing a disclosure index that comprises a range of items to check manually from the corporates' annual reports for certain years to determine the level of compliance (AgyeiMensah, 2017; Al Mutawaa \& Hewaidy, 2010; Al-Akra et al., 2010; Alanezi \& Albuloushi, 2011; Alfaraih, 2009; Alfraih \& Almutawa, 2017; Al-Jabri \& Hussain, 2012; Al-Shammari et al., 2008; Amoako \& Asante, 2012; Demir \& Bahadir, 2014; Fekete et al., 2008; Gutierrez Ponce et al., 2016; Juhmani, 2012, 2017; Karim \& Ahmed, 2005; Lopes \& Rodrigues, 2007; Tahat et al., 2016; Tauringana \& Chithambo, 2016; Tsalavoutas, 2011; Tsegba et al., 2017).

Buzby (1975) and Stanga (1976) were the first researchers to apply the notion of disclosure indices. Accordingly, the disclosure index is considered as a ratio to measure the actual disclosure level to the extent required, without resulting in the company being subjected to legal accountability for failing to disclose such information (Chavent, Ding, Fu, Stolowy, \& Wang, 2006). Recently, Tsalavoutas, Tsoligkas, and Evans (2018) provided a rich review of 81 studies related to compliance with IFRS mandatory disclosure requirements. They discussed a number of relevant issues, including the different types of disclosure indices used in literature, in addition to the disclosure scoring, validity, reliability, and materiality, which will be discussed extensively in later sections. They found that the majority of researchers used a self-constructed index, while the remaining few developed indices from previous studies or adopted indices from audit firms. They also found that around $44 \%$ of the sample adopted Cooke's method for scoring the index. On the other hand, very few studies mentioned the index validity and reliability together, despite their importance, and discussed the materiality. Thus, despite the considerable controversy surrounding the diversity of measuring compliance levels, which still continues, it has been demonstrated that the most common measurement used in previous studies was the index.

\subsubsection{Scoring the compliance index}

After constructing the index, the next key issue that has been widely debated is determining the most suitable approach for scoring the items on the checklist. There are several methods for scoring the compliance checklists, and Tsalavoutas, Tsoligkas, and Evans (2018) show the six main methods used by researchers as being: Cooke's method, Cooke's adjusted, the partial compliance

(PC) method, Saidin index, item by item, and counting items. Cooke's method, also referred to as the 'unweighted dichotomous approach', is the most common approach adopted by many studies (Abdul Rahman \& Hamdan, 2019; Agyei-Mensah, 2017; Alanezi \& Albuloushi, 2011; AlShammari, 2005; Demir \& Bahadir, 2014; Gutierrez Ponce et al., 2016; Juhmani, 2012, 2017; 
Marfo Yiadom \& Atsunyo, 2014; Mohammadi \& Mardini, 2016; Tauringana \& Chithambo, 2016; Tsegba et al., 2017). The dichotomous approach considers the total of all applicable items disclosed by a company to the maximum possible number of disclosure items that should be disclosed. Consequently, it is a ratio that excludes non-applicable items from the index. This approach is scored as 1 if an item is disclosed, and 0 if an item is not disclosed. By adding more options in the scoring process, Cooke's adjusted method relies on 1 for disclosed items, 0.5 for partial disclosure, and 0 for non-disclosed items (Hossain, 2014).

In partial compliance (PC), the ratio is measured by dividing the number of items disclosed by the firm by the sum of the items for each standard, and then dividing the output by the whole total of items. Cooke's method and the PC approach are considered to be unweighted, which gives equal weight to each item required to be disclosed. That means that the number of items included in each standard will not be affected, which gives objectivity a value to each item on its own. Moreover, using the PC unweighted approach can be applicable for measuring the compliance level for more than one standard, since the calculation for this approach requires the total items for each standard (Tsalavoutas et al., 2010). Therefore, for the purposes of this study, the dichotomous approach is employed.

The Saidin method measures the disclosure of items by finding the ratio of companies which do not disclose the items (Mazzi, André, Dionysiou, \& Tsalavoutas, 2017). This method in turn is described as a weighted measure, because it gives a certain range of weights for every IFRS disclosure item, and this indicates that companies with lower weights disclose more items, and vice versa (Hodgdon, Tondkar, Harless, \& Adhikari, 2008). Following the item-by-item method means that each item is tested separately and mandated by a certain authority, such as accounting standards (Tsalavoutas et al., 2018). Finally, the counting items method, in short, sums the total of the disclosed items in the index (Ebrahim, 2014).

The Cooke's and PC methods are the most commonly used approaches in literature, separately or together. Some studies show that there is no significant difference between the two approaches, since each method has its own criticisms and merits (Alsaeed, 2006; Lopes \& Rodrigues, 2007). However, Tsalavoutas, Evans, and Smith (2010) conclude that there is a clear relative difference between the two approaches, which in turn makes a difference to the expected effects of the issue that is measured. They clarify that using the two approaches together in a study enhances the results and sheds light on other influences concerning issues under study. In addition, using two methods or more for scoring the index can be considered to increase the robustness, enhancing the efficiency of the index and the compliance outcomes related to the selected sample under investigation (Tsalavoutas, Tsoligkas, \& Evans, 2018).

It is also important to note the techniques used by researchers during scoring of the index. One of the most known techniques is content analysis. Content analysis can take one of two forms: manual or computerised. The manual approach uses keywords for counting the disclosure by reading through every single observation (annual report) manually, which may be time consuming and 
take a significant amount of effort. In contrast, computerised content analysis can be completed in a shorter time with less effort as it relies on advanced software designed for this specific purpose (Ibrahim \& Hussainey, 2019; Weber, 1990). Both techniques have positive and negative points, but the researcher can decide on the most suitable approach for their study based on the different justifications.

\subsection{The research design}

This section outlines the required process that can be followed for constructing an index - the most common instrument used in accounting and disclosure literature. It covers the methods employed in this study, showing the steps for constructing an index. This section is divided into two parts: the first part provides a description of the selected sample, and the second part discusses the guideline which is, in turn, divided into five subsections - the basic source (the standard), materiality, reliability, validity, and the scoring method adopted for such an index.

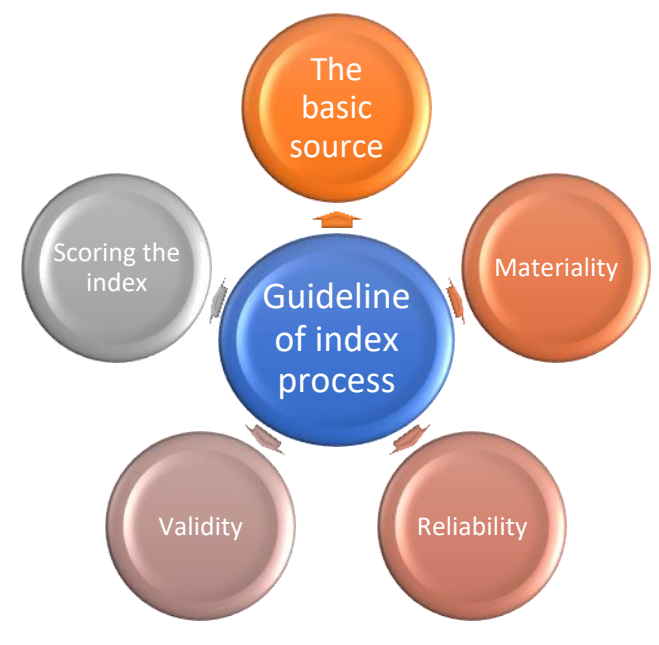

Figure 1 Index process and scoring

\subsubsection{The sample and data collection}

This study provides a descriptive and practical guideline in order to construct a disclosure index to measure compliance levels. Therefore, the sample selected is one of the IFRS standards, specifically the disclosure requirements of the financial instruments related to IFRS 7 . IFRS 7 has been selected to highlight the importance of financial instruments and their impact on financial information quality in general. It also reflects the growing interest in financial instruments among academics and practitioners, especially after the financial crisis of 2008, and frequent updates on IFRS 7. The constructed index will be applied to a number of listed banks from GCC countries, 
namely: Saudi Arabia, Bahrain, Oman, Qatar, Kuwait, and United Arab Emirates. The main focus is on the financial sector (banking sector), as it is considered to be one of the best sectors representing financial instruments, making it the most appropriate choice to apply the requirements of IFRS 7 (Allini et al., 2019). The differing business environments, especially between the Middle Eastern (developing countries) and Western countries (developed countries); the uniqueness of GCC countries as they share similar cultures, religion, and legal systems and the early mandatory adoption of IFRS in the financial sector; and the lack of studies conducted in such an environment all lead towards a focus on developing a new index to measure IFRS 7 compliance levels among GCC countries.

The whole sample consists of listed banks from GCC countries that have adopted IFRS mandatorily, except the Islamic banks as they adopt AAOIFI. However, a pilot study has been considered for certain parts of the research which includes a section of the whole study sample. The pilot study firstly consisted of listed banks in Saudi Arabia only, and then a limited number of banks from GCC countries were included to check the validity and reliability of the index. Table 1 shows in detail the number of banks included for the pilot study to complete the process for constructing the index. The period selected for the study is from 2011 to 2017. 2011 was selected as the starting point for the annual reports, based on the latest amendment issued by the IASB of IFRS 7 in 2010, which came into effect at the beginning of 2011. Likewise, 2017 was chosen as the latest period that would be covered by the study. Secondary sources were used to collect sample data, namely annual reports (whether from the stock markets' websites or the official websites of the banks), information from the official IFRS website, as well as any other useful sources, such as prior literature and auditing company websites.

Table 1 Selected sample

\begin{tabular}{lccccc}
\hline \multicolumn{1}{c}{ Sample } & Years & Countries & $\begin{array}{l}\text { No. } \\
\text { Banks }\end{array}$ & $\begin{array}{c}\text { No. Annual } \\
\text { Reports }\end{array}$ & \% \\
\hline Whole sample & $2011-2017$ & All GCC & 57 & 396 & $100 \%$ \\
\hline Reliability (stability) & $2015 \& 2016$ & Saudi Arabia & 6 & 12 & $3 \%$ \\
\hline $\begin{array}{l}\text { Reliability } \\
\text { (reproducibility) }\end{array}$ & 2016 & Saudi Arabia & 1 & 1 & $0.25 \%$ \\
\hline 를 & $2011-2017$ & All GCC & 6 & 42 & $10 \%$ \\
\hline Reliability (accuracy) & $2011-2017$ & All GCC & 6 & 42 & $10 \%$ \\
\hline Criterion validity & 2017 & All GCC & 6 & 6 & $1 \%$ \\
\hline $\begin{array}{l}\text { Index scoring } \\
\text { (robustness test) }\end{array}$ & $2011-2017$ & Saudi Arabia & 12 & 84 & $21 \%$ \\
Construct validity & $2011-2017$ & All GCC & 57 & 396 & $100 \%$ \\
\hline
\end{tabular}




\subsubsection{Guidelines for constructing the index}

In order to create an index that can measure the degree of compliance, the researcher suggests a number of steps. These steps are assumed to be followed by researchers who attempt to measure the degree of compliance in general, and with emphasis here on the accounting standards (IFRS). This guidance may lay down a number of significant basics which might be taken into consideration during construction of the index, and thus may help to develop research methodology and convergence between results. This guidance contains four steps - the main source, materiality, reliability, and validity - and finally a scoring formula which will be explained in the following sections.

\subsubsection{The basic source (original standard)}

With respect to mandatory disclosure, there are required elements that must be included in the annual reports. These elements are also subject to materiality (this concept will be discussed later) and some other conditions which make them more suitable to a certain sector. In this sense, researchers pointed to the need to refer to the main source of the requirements, the original standards issued by IASB, and to determine the mandated items that should be included for disclosure (Alanezi \& Albuloushi, 2011; Demir \& Bahadir, 2014).

Reading the entire standard and understanding every section is an important step when building a measurement index. Therefore, an important question must be answered: what kind of item is being looked for? If the purpose of the index is measuring disclosure, it is necessary to focus only on all the disclosure's requirements, and ignore those relating to presentation items or measurement methods used in financial operations. In addition, a researcher should recognise the repeating items sometimes mentioned in different parts of the standard, which must be avoided when creating the index. Another significant point that the researcher must be aware of is recognising significant dates: the issue date of the standard, the effective date for applying the standard by firms, dates of any changes/updates made to the standard, as well as the effective date of such updates.

By concentrating on IFRS 7, the complex nature of financial instruments makes the reading task of the standard much more difficult, especially when it comes to differentiating between presentation and disclosure requirements; this can lead to much confusion for researchers and financial report preparers. This issue leads the IASB to make continuous amendments to this standard (Deloitte, 2017a, 2017c). However, the standard covers all required disclosure items related to financial instruments in financial statements and their notes in addition to the qualitative information, such as the accounting policies followed by firms. Moreover, this standard has passed through many stages of development over several years. From the 1990s until 2014, the IASB continued to make amendments to IFRS 7 (Deloitte, 2017a, 2017b, 2017d, 2017e)(see Table 2). As a result, the version of the standard after update in 2010 has been taken in consideration for this study. This version covers the updates carried out to improve the standard, such as including 
further clarification of the required disclosures. This version was chosen for the present study because the effective date for applying these amendments was at the beginning of 2011, which is within the range of the study period.

Table 2 Dates of issuance and change of financial instruments standards

\begin{tabular}{|c|c|c|c|}
\hline Standard & Details & Issued & Effective \\
\hline $\begin{array}{l}\text { IAS 30: Disclosures in the } \\
\text { Financial Statements of } \\
\text { Banks and Similar Financial } \\
\text { Institutions }\end{array}$ & $\begin{array}{l}\text { Requirements for presentation and disclosure } \\
\text { concerning financial instruments by financial } \\
\text { institutions. }\end{array}$ & 1990 & $\begin{array}{l}\text { 1991-Replaced by } \\
\text { IFRS } 7\end{array}$ \\
\hline $\begin{array}{l}\text { IAS 32: Financial } \\
\text { Instruments: Presentation }\end{array}$ & $\begin{array}{l}\text { Requirements for the presentation of financial } \\
\text { instruments: assets, liabilities, equity, interest, } \\
\text { dividends and gains/losses. }\end{array}$ & 1995 & 1996 \\
\hline $\begin{array}{l}\text { IAS 39: Financial } \\
\text { Instruments: Recognition and } \\
\text { Measurement }\end{array}$ & $\begin{array}{l}\text { Requirements for the recognition and measurement of } \\
\text { financial assets, financial liabilities, and some contracts } \\
\text { of non-financial items. }\end{array}$ & 1998 & $\begin{array}{l}\text { 2001-Replaced by } \\
\text { IFRS } 9 \text { in } 2018\end{array}$ \\
\hline $\begin{array}{l}\text { IFRS 7: Financial } \\
\text { Instruments: Disclosures }\end{array}$ & $\begin{array}{l}\text { Requirements for disclosure of information about the } \\
\text { significance of financial instruments to an organisation }\end{array}$ & 2005 & 2007 \\
\hline IFRS 7: Amendments & $\begin{array}{l}\text { Some amendments were made to improve the standard } \\
\text { (clarification of disclosures) }\end{array}$ & 2010 & 2011 \\
\hline $\begin{array}{l}\text { IFRS 9: Financial } \\
\text { Instruments }\end{array}$ & $\begin{array}{l}\text { Requirements for recognition and measurement, } \\
\text { impairment, derecognition and general hedge } \\
\text { accounting. }\end{array}$ & 2014 & $\begin{array}{l}2018 \\
\text { (Permitted apply in } \\
2015)\end{array}$ \\
\hline
\end{tabular}

\subsubsection{Item materiality}

Reading the standard as the main source for obtaining the required information and disclosure items is considered to be the first step in establishing an index. Being aware of the standard and its history gives a good indication of the compliance process requirements. The next important step is the materiality of the items, or in other words, the relevance of chosen items. Most compliance studies that construct an index as a research tool pass through this step; however, they do not clearly indicate the details. Despite the importance of this step, many researchers may not be aware of the significant discussion and clarification needed during this step as a part of the process for preparing the index. Therefore, materiality was one of the factors that led the researcher to address this matter in this section of the study; the researcher faced difficulties relating to this issue while constructing the index, and there were no clear points or directions show how to exclude irrelevant items and choose the most appropriate ones. Materiality has been defined as "presenting a substantial likelihood that the disclosure of the omitted fact would have been viewed by the reasonable investor as having significantly altered the total mix of information made available" (Khan, Serafeim, \& Yoon, 2016, p.9). Accordingly, this process is a kind of items revision, where 
judgements are made towards the content of the index for it to become more rational in measuring the degree of compliance, and more fair in demonstrating the compliance results.

Many researchers believe that including as many items as possible is a good indicator of the quality of the index, but there may be a large part of bias in this. It is necessary to distinguish between those required items that can be scored as non-compliance, and items that are not appropriate/relevant for that sector or entity ('not applicable'). Inserting the items in an index is therefore subject to certain judgements ${ }^{2}$ that are made by researchers and other parties such as auditors, management, or financial report preparers. The lack of references in this area is confirmed by Tsalavoutas, Tsoligkas, and Evans (2018) in their review study. They found that very few studies (eight studies out of 81) discuss, to some extent, the materiality issue. They also note that all of these studies were conducted in disclosures relating to goodwill and impairment. This may indicate a lack of knowledge of the importance of this aspect by researchers, and therefore they did not take much of their attention and so, perhaps, this is considered one of the causes of differing compliance results and contradiction in some of the findings of previous studies.

When preparing the disclosure index for IFRS 7, assistance was requested from a professional accredited auditor from one of the Big 4 auditing companies (KPMG) to check the appropriate items for the index. As a specialised auditor in this field, this auditor has relevant, practical experience with IFRS implementation, and he is aware of the required items that must be included in financial reports. After careful reading of IFRS 7 by the researcher and the auditor, it was agreed that the original standard includes some repeated items, ${ }^{3}$ as well as irrelevant items within the period of the selected sample such as those correlated with IFRS 9. Consequently, there were a number of phases to go through before arriving at the last version of the index. As a starting point, we took into consideration all the items mentioned in the standard $(n=292)$, in no specific order or category. Following this, all repeated items were removed as well as any items relating to presentation or measurement, or any items that were considered to be supplementary information rather than clear requirements. A new total of items was reached, totalling 130. All requirements related to the last updates in 2010 but effective after June 2011 were then eliminated, along with all periods after that date, and the new total came to 103 . Then, the items were categorised under specific titles, for example the titles of basic financial statements, and this reduced the total to 82 items. A final review was made to identify the items that were not applicable for the selected sample (banks), and the final number of items for the index was reached: 76 items (Table 3).

\footnotetext{
${ }^{2}$ Some items in note 10 required some judgement by the researcher, as some of these items are subject to several requirements belonging to IFRS 9, the standard dealing with financial instrument measurements.

${ }^{3}$ Repeated items such as the amount of maximum exposure to credit risk were repeated in note 9 and 36.
} 
Table 3 Materiality phases for final index

\begin{tabular}{c|cl} 
Phases & Items & \multicolumn{1}{c}{ Removing Information } \\
\hline Phase 1 & 292 & $\begin{array}{l}\text { Repeated items, items related to presentation or measurement, } \\
\text { items were supplementary }\end{array}$ \\
Phase 2 & 130 & $\begin{array}{l}\text { Effective requirements after June in 2011, and all the periods after } \\
\text { that date }\end{array}$ \\
Phase 3 & 103 & $\begin{array}{l}\text { Categorising and grouping the items under specific titles } \\
\text { Phase 4 }\end{array}$ \\
Last phase & 76 & $\begin{array}{l}\text { Identifying non-applicable items } \\
\text { (Final index) }\end{array}$
\end{tabular}

\subsubsection{Index reliability}

Reliability refers to the consistency in measuring the index's results. This means that the coding or measuring done by one or more than one person, and for more than one time, leads to the same result without differences. Accordingly, reliability has three forms: stability, reproducibility, and accuracy (Hussainey, 2004). Stability means that measuring or scoring the index is completed many times by one person - the researcher or the index's constructor. Reproducibility can be conducted by a group of people (more than one individual) when scoring the index. However, the researchers noticed that the agreement between the coders might be a result of chance or randomicity. Therefore, different tests (Scott's pi, Krippendorff's alpha, Cohen's kappa) have been addressed to overcome this issue. Accuracy explains the internal consistency between items within the index. Each form is expressed in a particular method, and it is assumed that all of these methods support the reliability approach (Hassan \& Marston, 2018; Hussainey, 2004; Kavitha \& Nandagopal, 2011).

After completing the disclosure index related to IFRS 7 in its final version of items, its reliability was verified as a part of the pilot study, and accordingly, a number of tests were conducted for that purpose. The researcher (one coder) took a section of the whole sample (12 observations out of 396) to check the stability by scoring 12 annual reports of six listed banks in Saudi Arabia from 2015 and 2016. Then, after a month, the researcher re-scored the same 12 annual reports. The results of the index scoring were the same both times. In addition to the stability, the researcher checked the reproducibility (more than one coder) by consulting two groups. The first group consisted of three academics and one professional accountant, and due to the limited timescale, one annual report was sent to them for coding. Two items were discussed with one participant regarding clarification of the desired context. Forty-two annual reports, one bank from each country from 2011 until 2017, and 10\% from the whole sample were coded by one auditor from KPMG and the researcher, who comprised the second group. The coding errors between the two coders were limited to two annual reports, otherwise there was agreement among the rest of the annual reports. The differences arose because of two points. Firstly, there was a difference in the 
understanding and interpretation of certain terms, such as those relating to financial assets and those relating to property and equipment assets. The second point relates to the search terms or words used in the content analysis. All points of disagreement were discussed and understood to the point where all parties agreed. Consequently, the coefficient of agreement was 95\% (40/42), which increases the level of reliability of the measurement instrument (index) used for the study. With respect to accuracy, a Cronbach's alpha test is typically used in most literature, which helps to measure the internal consistency between the items in the index. Here, alpha is equal to $89 \%$, which is considered a good score, and this in turn increases the level of reliability of the index employed for this study (Rouf \& Akhtaruddin, 2018).

\subsubsection{Index validity}

Validity is another aspect that enhances the ability of the index (measurement tool) to measure the phenomenon under study, and to identify the concepts that the researcher wants to study. Carmines and Zeller (1979) define validity as "the extent to which any measuring instrument measures what it is intended to measure"(p.17). There are three common forms of validity, namely: content validity (face validity), criterion validity, and construct validity (Hassan \& Marston, 2018; Hussainey, 2004). However, reviewing prior literature revealed that discussions of the precise concept of validity - and in deep detail with the different forms - are very few.

Content validity, also known as 'face validity', points to the role of the various judgements made by different parties, whether professionals or not, in evaluating the quality of the index and whether it is capable of effectively measuring what the researcher wants it to. Despite the role of these judgements being important, it may not be considered in some cases as an effective and convincing step, as those individuals/arbitrators may differ in the perceptions on which their judgements or assessments are based (Hassan \& Marston, 2018). Criterion validity simply provides a comparison between the indices either existing in literature or predicted, and the one that is employed for a study. The higher the correlation between them, the stronger the validity that can be achieved. This type of correlation promotes the validity of the index and its ability to measure and reflect the issue. Construct validity has been widely accepted among researchers in science research, as this form enhances the link between the prepared index and external variables mentioned in previous literature, such as the firms' characteristics (Babaghaderi, Bhabra, \& Kolahgar, 2018; Hassan \& Marston, 2018; Weber, 1990).

Based on the sample of this study, content validity has been waived as the researcher already considered a similar step in the reliability process (reproducibility). An annual report was sent to four individuals (three academics and one accountant), and accordingly, a discussion took place regarding some items and amendments thereto. Moreover, criterion validity was checked through comparing the present index with another study's index, namely that of Tahat, Mardini, and Power (2017). A sample of six annual reports (one from each country from 2017) was scored with the 
two indices. The correlation coefficient was $89 \%$, which is considered a correlation between the two indices, and this in turn enhances the validity of the current index.

To check the last form of validity (construct), three variables related to corporations' features were taken into consideration: firm size, profitability, and leverage ratio. In fact, several studies have investigated compliance determinants, such as firm size, firm age, leverage ratio, profitability, and industry, and they consequently reveal mixed results. However, Samaha and Khlif (2016) in their meta-analysis study showed that the determinants that can influence compliance with IFRS in developing countries the most are firm size (Abdul Rahman \& Hamdan, 2017; Al Mutawaa \& Hewaidy, 2010; Alrawahi \& Sanad, 2016; Al-Sartawi, Al-Shammari et al., 2008; Bova \& Pereira, 2012; Hodgdon, Tondkar, Adhikari, \& Harless, 2009; Hossain, 2014; Samaha \& Stapleton, 2009; Tahat et al., 2017; Tauringana \& Chithambo, 2016; Tsegba et al., 2017), leverage (Al-Akra et al., 2010; Al-Sartawi et al., 2016; Al-Shammari et al., 2008; Bova \& Pereira, 2012; Hossain, 2014; Karim \& Ahmed, 2005; Tauringana \& Chithambo, 2016), profitability (Al-Akra et al., 2010; Al Mutawaa \& Hewaidy, 2010; Alrawahi \& Sarea, 2016; Bova \& Pereira, 2012; Elshandidy, 2011; Tsegba et al., 2017), and the type of auditor's firm (Alrawahi \& Sarea, 2016; Appiah, AwunyoVitor, Mireku, \& Ahiagbah, 2016; Juhmani, 2017). For the present study, the variables that will be examined are firm size, leverage, and profitability. The type of auditor's firm is not suitable for this study because it was found that all the banks in the sample adopt at least one, usually two, of the Big 4 auditing companies. The results of the correlation test show a correlation between the disclosure index and the selected variables. The correlation coefficients between the index and firm size, profitability, and leverage are $0.29,0.27$, and -0.24 , respectively, and have p-values of less than $1 \%$.

Table 4 Pearson correlations (validity construct)

\begin{tabular}{|c|c|c|c|c|}
\hline & D.INDX & F.SIZE & PROF & $L E V R$ \\
\hline D.INDX & 1 & & & \\
\hline F.SIZE & $.294^{* *}$ & 1 & & \\
\hline PROF & $.277^{* *}$ & $.333^{* *}$ & 1 & \\
\hline LEVR & $-.241^{\star \star}$ & -.059 & $-.177^{\star \star}$ & 1 \\
\hline
\end{tabular}

\subsubsection{Index scoring}

In line with prior literature, and for the purposes of the current study, Cooke's method has been applied to score the disclosure index of IFRS 7 requirements: 1 for disclosed items, 0 for nondisclosed items, excluding non-applicable items. Moreover, for robustness purposes, the counting items method has been applied as additional analysis for scoring the index. By applying the two 
methods of scoring - Cooke's and counting items methods - on 12 listed banks from Saudi Arabia (pilot study on a partial sample; 84 annual reports) from 2011 until 2017, it can be noted that the differences between the two methods are very small and almost negligible (Table 5). A MannWhitney test shows that the p-value of $0.293(29.3 \%)$ is greater than $5 \%$, and therefore the calculation of compliance levels under Cooke's method does not differ from the method of counting items; that is, the difference between the two methods is insignificant. This, in turn, increases the robustness of the index employed for the current study.

Table 5 Robustness test for scoring the index method applied

\begin{tabular}{|l|c|c|c|c|c|c|c|c|}
\hline Scoring Banks & 2011 & 2012 & 2013 & 2014 & 2015 & 2016 & 2017 & $2011-2017$ \\
\hline Cooke's Method & 0.8183 & 0.8250 & 0.8267 & 0.8308 & 0.8325 & 0.8308 & 0.8292 & 0.8276 \\
\hline Counting items & 0.8300 & 0.8257 & 0.8279 & 0.8322 & 0.8333 & 0.8311 & 0.8289 & 0.8299 \\
\hline
\end{tabular}

\subsection{Findings and discussion}

Table 6 summarises the entire process conducted above for constructing the disclosure index. It shows all the different stages that the index passed through for measuring the compliance level, specifically with the requirements of IFRS 7 . The table shows that the processes followed to construct the index were basic source, materiality, reliability, validity, and scoring formula. The explanation for each process is provided: basic source includes reading and analysing the original source of the items (IFRS 7); materiality focuses on carefully revising the relevant items and classifying them as a way to meet the purpose of the study without neglecting any important items that would affect the achievement of the desired results; reliability checks the consistency in measuring the index's total; validity tests the extent to which the index can measure the compliance level; and the scoring formula, among a number of techniques, was adopted for scoring the items of the index, which in this study is an unweighted dichotomous approach (Cooke's method). Accordingly, these results can answer the study's question of what the steps are for constructing a compliance index with IFRS 7, by applying the previous steps on the standard.

The results show that item materiality is considered the cornerstone that the index can be built upon; that is, this stage needs some assistance regarding the judgements related to the relevant items from different parties - the researchers and professionals. Moreover, reliability and validity are two sides of a single coin, intended to determine the robustness and ability of the index to interpret the expected results as correctly as possible. For this reason, the distinction between these two concepts is important for the researcher in order to complete validation procedures. Consequently, it is clear that reliability and validity are similar in some places, such as the first form of validity (content) and the second form of reliability (reproducibility), however it is 
necessary to distinguish between reliability and validity in order to obtain a high degree of confidence with the index employed. While reliability focuses on reaching the same results from coding by multiple individuals, validity is concerned with the extent to which variables can interpret the phenomenon that the researcher wants to test. 
Table 6 Constructing an index process

\begin{tabular}{|c|c|c|c|c|}
\hline Process & Explanation & \multicolumn{3}{|c|}{ Details } \\
\hline $\begin{array}{l}\text { 1. Basic } \\
\text { Source }\end{array}$ & $\begin{array}{l}\text { Reading, understanding, } \\
\text { and checking the updates. }\end{array}$ & $\begin{array}{l}\text { The original standard of IFRS } \\
7\end{array}$ & & \\
\hline $\begin{array}{l}\text { 2. Items } \\
\text { Materiality }\end{array}$ & $\begin{array}{l}\text { The relevance of chosen } \\
\text { items and context }\end{array}$ & $\begin{array}{l}\text { Starting from } 292 \text { until } 76 \\
\text { items. }\end{array}$ & & \\
\hline 3. Reliability & $\begin{array}{l}\text { The consistency in } \\
\text { measuring the index's } \\
\text { results }\end{array}$ & $\begin{array}{l}\text { Stability: Scoring } 12 \text { annual } \\
\text { reports from six listed banks } \\
\text { in Saudi Arabia twice by the } \\
\text { researcher, leading to the } \\
\text { same results }\end{array}$ & $\begin{array}{l}\text { Reproducibility: } \\
\text { - Three academics and one } \\
\text { professional accountant } \\
\text { coded one annual report, } \\
\text { and then two items were } \\
\text { amended. } \\
\text { - } 42 \text { annual reports coded by } \\
\text { one auditor from KPMG } \\
\text { and the researcher and the } \\
\text { coefficient of agreement } \\
\text { was } 90 \% \text {. }\end{array}$ & $\begin{array}{l}\text { Accuracy: Cronbach's } \\
\text { alpha test for the internal } \\
\text { consistency which is } 89 \%\end{array}$ \\
\hline 4. Validity & $\begin{array}{l}\text { The extent to which any } \\
\text { measuring instrument } \\
\text { measures what it is } \\
\text { intended to measure }\end{array}$ & $\begin{array}{l}\text { Content: has been waived, } \\
\text { because of its similarity with } \\
\text { the second form of reliability } \\
\text { (reproducibility). }\end{array}$ & $\begin{array}{l}\text { Criterion: comparing the } \\
\text { present index with another } \\
\text { study's index of Tahat et al. } \\
\text { (2017) for six annual reports. } \\
\text { The correlation coefficient } \\
\text { was } 89 \% \text {. }\end{array}$ & $\begin{array}{l}\text { Construct: There is a strong } \\
\text { correlation between the } \\
\text { disclosure index and the } \\
\text { selected variables: firm size } \\
(0.29) \text {, profitability }(0.27) \\
\text { and leverage }(-0.24) \text {. }\end{array}$ \\
\hline $\begin{array}{l}\text { 5. Scoring } \\
\text { the index }\end{array}$ & $\begin{array}{l}\text { The strategy adopted for } \\
\text { scoring the items of the } \\
\text { index }\end{array}$ & $\begin{array}{l}\text { Unweighted dichotomous } \\
\text { approach (Cooke's method) } \\
\text { adopted. }\end{array}$ & $\begin{array}{l}\text { Counting items method has } \\
\text { been applied as robustness } \\
\text { analysis with Cooke's } \\
\text { method. There was no } \\
\text { difference between the } \\
\text { outcomes by the two } \\
\text { methods. }\end{array}$ & \\
\hline
\end{tabular}




\subsection{Conclusion}

This study, as mentioned previously, explains one of the most significant parts related to measuring compliance levels. One main research question was addressed in this study: what are the steps (guidelines) suggested for constructing a compliance index? This question sheds light on the relevant steps that might be considered by researchers in order to construct an index for compliance purposes in general. These steps are basic source, materiality, reliability, validity, and scoring methods, and every step has been discussed in detail in this study. To provide empirical evidence for these steps, the disclosure requirements of IFRS 7 were considered for constructing an index. The index was applied on a sample of listed banks from GCC countries. The content (materiality) of the index varied from 292 items at the first stage, to a total of 76 items at the final stage. The three forms of reliability (stability, reproducibility, and accuracy) and the other three forms of validity (content, criterion, and construct) were applied in constructing the IFRS 7 index. Moreover, this study presents the different methods used for scoring and calculating the index, and the results indicate the most common method (Cooke's method) is the most appropriate, and is applied in the study.

Thus, the diversity in the ways of constructing an index and ensuring its reliability and efficiency, as well as the choice of calculation methods, may lead to a variety of results in compliance studies. Application of such steps may help reduce these differences in study results. However, this does not mean that it is necessary to go through all the forms mentioned in the study. It might be significant to conduct at least one form from each stage, which will promote the measurement instrument (the index).

Like any research, this study has its shortcomings. It focuses only on the disclosure requirements, and therefore it would benefit from a focus on other types of requirement such as measurement and presentation requirements. Since it addresses only one standard, this in turn can limit the application of some methods of scoring, such as the PC method, that requires more than one standard with different categories. Further, reviewing previous literature as well as Tsalavoutas, Tsoligkas, and Evans' (2018) study shows that the most common methods applied when scoring indices are Cooke's and PC methods. This, in turn, suggests that more attention might be given to the other methods by future researchers, providing they can be demonstrated as being robust enough to enhance the validity of the index and are able to interpret the phenomenon under study. This study did not consider the differences between Islamic and non-Islamic banks, and this issue could also be addressed in the future. Lastly, further studies may pay more attention to the measurement of non-financial sectors.

\section{Conflict of Interest Statement}

On behalf of all authors, the corresponding author states that there is no conflict of interest. 


\section{References}

Abdul Rahman, A., \& Hamdan, M. D. (2017). The extent of compliance with FRS 101 standard: Malaysian evidence. Journal of Applied Accounting Research, 18(1), 87-115. https://doi.org/10.1108/JAAR-10-2013-0078.

Abdul Rahman, A., \& Hamdan, M. D. (2019). An investigation of the level of compliance with financial reporting standards (FRS 101) by Malaysian SMEs. Journal of Economic Info, 6(1), 26-33.

Achim, A. M., \& Chis, A. O. (2014). Financial accounting quality and its defining characteristics. SEA Practical Application of Science, 2(3).

Agyei-Mensah, B. K. (2017). The relationship between corporate governance mechanisms and IFRS 7 compliance: Evidence from an emerging market. Corporate Governance (Bingley), 17(3), 446-465. https://doi.org/10.1108/CG-06-2016-0129.

Agyei-Mensah, B. K. (2019). IAS-38 disclosure compliance and corporate governance: Evidence from an emerging market. Corporate Governance: The International Journal of Business in Society.

Ahmed, A. (2012). Disclosure of financial reporting and firm structure as a determinant: A study on the listed companies of DSE. ASA University Review, 6(1). https://doi.org/10.1002/pon.4272.

Al-Akra, M., Eddie, I. A., \& Ali, M. J. (2010). The influence of the introduction of accounting disclosure regulation on mandatory disclosure compliance: Evidence from Jordan. British Accounting Review, 42(3), 170-186. https://doi.org/10.1016/j.bar.2010.04.001.

Al-Jabri, H., \& Hussain, M. (2012). Compliance with international accounting standards requirements among Omani listed companies. Journal of Administrative and Economic Sciences, Qassim University, 5(2), 75-105.

Al-Sartawi, A. M. A. M., Alrawahi, F., \& Sanad, Z. (2016). Corporate governance and the level of compliance with International Accounting Standards (IAS-1): Evidence from Bahrain Bourse. International Research Journal of Finance and Economics, (157), 110-122. Retrieved from http://www.internationalresearchjournaloffinanceandeconomics.com.

Al-Shammari, B. (2005). Compliance with international accounting standards by listed companies in the Gulf Co-operation Council member states: An empirical study. University of Western Australia.

Al-Shammari, B. (2011). Factors influencing the extent of mandatory compliance with international financial reporting standards: The case of Kuwaiti listed companies. Journal of International Business and Economics, 11(4), 305-360.

Al-Shammari, B., Brown, P., \& Tarca, A. (2008). An investigation of compliance with international accounting standards by listed companies in the Gulf Co-Operation Council member states. International Journal of Accounting, 43(4), 425-447. https://doi.org/10.1016/j.intacc.2008.09.003.

Al Mutawaa, A., \& Hewaidy, A. (2010). Disclosure level and compliance with IFRSs: An empirical investigation of Kuwaiti companies. The International Business \& Economics Research Journal, 9(5), 33.

Alanezi, F. S., \& Albuloushi, S. S. (2011). Does the existence of voluntary audit committees really affect IFRS-required disclosure the Kuwaiti evidence?International Journal of Disclosure and Governance, 8(2), 148-173. https://doi.org/10.1057/jdg.2010.33.

Alanezi, F. S., Alfaraih, M. M., Alrashaid, E., \& Albolushi, S. S. (2012). Dual/joint auditors and the level 
of compliance with international financial reporting standards (IFRS-required disclosure): The case of financial institutions in Kuwait. Journal of Economic and Administrative Sciences, 28(2), 109129. https://doi.org/10.1108/10264111211248402.

Alfaraih, M. (2009). Compliance with international financial reporting standards (IFRS) and the value relevance of accounting information in emerging stock markets: evidence from Kuwait. Queensland University of Technology. https://doi.org/36377.

Alfraih, M. M., \& Almutawa, A. M. (2017). Voluntary disclosure and corporate governance: Empirical evidence from Kuwait. International Journal of Law and Management, 59(2), 217-236. https://doi.org/10.1108/IJLMA-10-2015-0052.

Allini, A., Ferri, L., Maffei, M., \& Zampella, A. (2019). 'Compliance to IFRS 7: Evidence from the Italian banking sector'. In G. Garzone \& W. Giordano (Eds.), Discourse, Communication and the Enterprise: Where Business Meets Discourse (p. 298). Newcastle: Cambridge Scholars Publishing.

Alrawahi, F. E., \& Sarea, A. M. (2016). An investigation of the level of compliance with international accounting standards (IAS 1) by listed firms in Bahrain Bourse. International Journal of Islamic and Middle Eastern Finance and Management, 9(2), 254-276. https://doi.org/10.1108/IMEFM-07-20150077.

Alsaeed, K. (2006). The association between firm-specific characteristics and disclosure. Managerial Auditing Journal, 21(5), 476-496. https://doi.org/10.1108/02686900610667256.

Amoako, G., \& Asante, S. (2012). Compliance with international financial reporting standard 7 (IFRS 7): A study of listed banks in Ghana. Research Journal of Finance and Accounting, 3(4), 66-73.

Appiah, K. O., Awunyo-Vitor, D., Mireku, K., \& Ahiagbah, C. (2016). Compliance with international financial reporting standards: The case of listed firms in Ghana. Journal of Financial Reporting and Accounting, 14(1), 131-156. https://doi.org/10.1108/JFRA-01-2015-0003.

Baazaoui, H. (2019). The effect of firm characteristics on the disclosure of IAS/IFRS information: The cases of Tunisia, France and Canada. International Business and Accounting Research Journal, $3(2)$.

Babaghaderi, A., Bhabra, H., \& Kolahgar, S. (2018). Impact of Firm's Communication and Disclosure on Risk and Value.

Ballas, A., Sykianakis, N., Tzovas, C., \& Vassilakopoulos, C. (2018). Measuring compliance with IFRS mandatory disclosure requirements: Some evidence from Greece. In Perspectives, Trends, and Applications in Corporate Finance and Accounting, 273-300. https://doi.org/IGI Global.

Bamber, M. (2011). An examination and assessment of mandatory financial instruments disclosures. University of Exeter. Retrieved from http://hdl.handle.net/10036/3375.

Black, E. L. (2012). IFRS convergence and adoption: Challenges and opportunities. Journal of International Accounting Research, 11(1), 1. https://doi.org/10.2308/jiar-10230.

Bova, F., \& Pereira, R. (2012). The determinants and consequences of heterogeneous IFRS compliance levels following mandatory IFRS adoption: Evidence from a developing country. Journal of International Accounting Research, 11(1), 83-111.

Bravo Urquiza, F., Abad Navarro, M. C., \& Trombetta, M. (2009). Disclosure indices design: Does it make a difference? Revista de Contabilidad, 12(2), 253-277. https://doi.org/10.1016/S11384891(09)70008-1. 
Buzby, S. L. (1975). Company size, listed versus unlisted stocks, and the extent of financial disclosure. Journal of Accounting Research, 13(1), 16-37. https://doi.org/10.2307/2490647.

Carmines, E., \& Zeller, R. (1979). Reliability and validity assessment. SAGEPublications.

Chavent, M., Ding, Y., Fu, L., Stolowy, H., \& Wang, H. (2006). Disclosure and determinants studies: An extension using the Divisive Clustering Method (DIV). European Accounting Review, 15(2), 181218. https://doi.org/10.1080/09638180500253092.

Coy, D., \& Dixon, K. (2004). The public accountability index: Crafting a parametric disclosure index for annual reports. British Accounting Review, 36(1), 79-106. https://doi.org/10.1016/j.bar.2003.10.003.

Crawford Camiciottoli, B. (2013). Rhetoric in financial discourse: A linguistic analysis of ICT-mediated disclosure genres. Amsterdam: Rodopi BV.

Deloitte. (2017a). IAS 30 - Disclosures in the Financial Statements of Banks and Similar Financial Institutions. Retrieved April 3, 2017, from IASPlus website: https://www.iasplus.com/en/standards/ias/ias30\#link0

Deloitte. (2017b). IAS 32 - Financial Instruments: Presentation. Retrieved July 20, 2017, from IASPlus website: https://www.iasplus.com/en/standards/ias/ias32

Deloitte. (2017c). IAS 39 - Financial Instruments: Recognition and Measurement. Retrieved April 3, 2017, from IASPlus website: https://www.iasplus.com/en-gb/standards/ias/ias39

Deloitte. (2017d). IFRS 7 — Financial Instruments: Disclosures. Retrieved April 3, 2017, from IASPlus website: https://www.iasplus.com/en-gb/standards/ifrs-en-gb/ifrs7

Deloitte. (2017e). Standards. Retrieved April 3, 2017, from IASPlus website: https://www.iasplus.com/en-gb/standards

Demir, V., \& Bahadir, O. (2014). An investigation of compliance with International Financial Reporting Standards by listed companies in Turkey. Accounting \& Management Information Systems / Contabilitate Si Informatica de Gestiune, 13(1), 4-34. Retrieved from http://escweb.lib.cbs.dk/login?url=http://search.ebscohost.com/login.aspx?direct=true \&db=bth\&AN=971125 $50 \&$ site $=$ ehost-live $\&$ scope $=$ site .

Ebrahim, A. (2014). IFRS compliance and audit quality in developing countries: The case of income tax accounting in Egypt. Journal of International Business Research, 13(2), 19-37.

Ebrahim, A., \& Abdel Fattah, T. (2015). Corporate governance and initial compliance with IFRS in emerging markets: The case of income tax accounting in Egypt. Journal of International Accounting, Auditing and Taxation, 24, 46-60. https://doi.org/10.1016/j.intaccaudtax.2015.02.003.

Elshandidy, T. (2011). Risk Reporting Incentives: A Cross-Country Study. University of Stirling.

Elshandidy, T., Fraser, I., \& Hussainey, K. (2015). What drives mandatory and voluntary risk reporting variations across Germany, UK and US? British Accounting Review, 47(4), 376-394. https://doi.org/10.1016/j.bar.2014.06.001.

Fekete, S., Matis, D., \& Lukács, J. (2008). Factors influencing the extent of corporate compliance with IFRS: The case of Hungarian listed companies. SSRN 1295722.

Gutierrez Ponce, H., Hlaciuc, E., Mates, D., \& Maciuca, G. (2016). Empirical study of financial disclosure compliance with IFRS: Evidence from listed Romanian companies. Journal of Accounting and Auditing: Research \& Practice, 2016(July), 11. https://doi.org/10.5171/2016.794159. 
Halbouni, S. S., \& Yasin, A. (2016). Risk disclosure: Empirical investigation of UAE companies' compliance with international accounting standards. International Journal of Business and Management, 11(8), 134. https://doi.org/10.5539/ijbm.v11n8p134.

Hassan, O. A., \& Marston, C. (2018). Corporate financial disclosure measurement in the empirical accounting literature: A review article. International Journal of Accounting.

Hla, D. T., Hassan, A., \& Shaikh, J. M. (2013). IFRS compliance and nonfinancial information in annual reports of Malaysian firms. The IUP Journal of Accounting Research \& Audit Practices, XII(4), 724.

Hodgdon, C., Tondkar, R. H., Adhikari, A., \& Harless, D. W. (2009). Compliance with International Financial Reporting Standards and auditor choice: New evidence on the importance of the statutory audit. International Journal of Accounting, 44(1), 33-55. https://doi.org/10.1016/j.intacc.2008.12.003.

Hodgdon, C., Tondkar, R. H., Harless, D. W., \& Adhikari, A. (2008). Compliance with IFRS disclosure requirements and individual analysts' forecast errors. Journal of International Accounting, Auditing and Taxation, 17(1), 1-13. https://doi.org/10.1016/j.intaccaudtax.2008.01.002.

Hossain, I. (2014). Regulatory compliance of IFRS 7 of the banks' disclosures: A case study on the nationalized commercial banks of Bangladesh. Banglavision, 13(1), 186-201.

Hossain, M. A. (2002). Disclosure index approach in accounting research: A review of related issues.https://www.academia.edu/8030787/Disclosure_Index_Approach_in_Accounting_Research_ A_Review_of_Related_Issues.

Hussainey, K. (2004). Study of the ability of (partially) automated disclosure scores to explain the information content of annual report narratives for future earnings. University of Manchester.

Ibrahim, A., \& Hussainey, K. (2019). Developing the narrative risk disclosure measurement. International Review of Financial Analysis.

Jonas, G. J., \& Blanchet, J. (2000). Assessing quality of financial reporting. Accounting Horizons, 14, pp. 353-363. https://doi.org/10.2308/acch.2000.14.3.353.

Juhmani, O. (2012). Factors influencing the extent of corporate compliance with IFRS: Evidence from companies listed in Bahrain Stock Exchange. Journal of International Business and Economics, 12(2), 67-79.

Juhmani, O. (2017). Corporate governance and the level of Bahraini corporate compliance with IFRS disclosure. Journal of Applied Accounting Research, 18(1), 22-41. https://doi.org/10.1108/JAAR05-2015-0045.

Karim, A., \& Ahmed, J. (2005). Determinants of IAS disclosure compliance in emerging economies: Evidence from exchange listed companies in Bangladesh. Wellington, New Zealand.

Kavitha, D., \& Nandagopal, R. (2011). Disclosure studies - A commentary on the methods and measures. Indian Journal of Corporate Governance, 4(1). https://doi.org/10.1177/0974686220110103.

Khan, M., Serafeim, G., \& Yoon, A. (2016). Corporate sustainability: First evidence on materiality. Accounting Review. https://doi.org/10.2308/accr-51383.

Lee, E., Walker, M., Christensen, H. B., \& Zhao, R. (2010). Mandating IFRS: Its impact on the cost of equity capital in Europe. Journal of International Accounting Research, 9.

https://doi.org/10.2308/jiar.2010.9.1.58. 
Li, X., \& Yang, H. I. (2016). Mandatory financial reporting and voluntary disclosure: The effect of mandatory IFRS adoption on management forecasts. Accounting Review, 91(3), 933-953. https://doi.org/10.2308/accr-51296.

Lopes, P. T., \& Rodrigues, L. L. (2007). Accounting for financial instruments: An analysis of the determinants of disclosure in the Portuguese stock exchange. International Journal of Accounting, 42(1), 25-56. https://doi.org/10.1016/j.intacc.2006.12.002.

Marfo Yiadom, E., \& Atsunyo, W. (2014). Compliance with International Financial Reporting Standards by listed companies in Ghana. International Journal of Business and Management, 9(10), p87. https://doi.org/10.5539/ijbm.v9n10p87.

Mazzi, F., André, P., Dionysiou, D., \& Tsalavoutas, I. (2017). Compliance with goodwill-related mandatory disclosure requirements and the cost of equity capital. Accounting and Business Research, 47(3), 268-312. https://doi.org/10.1080/00014788.2016.1254593.

Mohammadi, A., \& Mardini, G. H. (2016). Financial instruments disclosure: The case of Qatari listed banks. Afro-Asian J. of Finance and Accounting, 6(2), 160. https://doi.org/10.1504/AAJFA.2016.077335.

Palmieri, R., Perrin, D., \& Whitehouse, M. (2018). The pragmatics of financial communication. Part 1: From sources to the public sphere. International Journal of Business Communication, 55(2), 127 134.

Pivac, S., Vuko, T., \& Cular, M. (2017). Analysis of annual report disclosure quality for listed companies in transition countries. Economic Research-Ekonomska Istrazivanja, 30(1), 721-731. https://doi.org/10.1080/1331677X.2017.1311231.

Rouf, M. A., \& Akhtaruddin, M. (2018). Factors affecting the voluntary disclosure: A study by using smart PLS-SEM approach. International Journal of Law and Management, 60(6), 1498-1508. https://doi.org/10.1108/IJLMA-01-2018-0011.

Samaha, K., \& Khlif, H. (2016). Adoption of and compliance with IFRS in developing countries. Journal of Accounting in Emerging Economies, 6(1), 33-49. https://doi.org/10.1108/JAEE-02-2013-0011.

Samaha, K., \& Stapleton, P. (2009). Firm-specific determinants of the extent of compliance with international accounting standards in the corporate annual reports of companies listed on the Egyptian Stock Exchange: A positive accounting approach. Afro-Asian Journal of Finance and Accounting, 1(3), 266-294. https://doi.org/10.1504/aajfa.2009.024302.

Stanga, K. (1976). Disclosure in published annual reports. Financial Management, (Winter), 42-52.

Tahat, Y. A., Dunne, T., Fifield, S., \& Power, D. M. (2016). The impact of IFRS 7 on the significance of financial instruments disclosure. Accounting Research Journal, 29(3), 241-273. https://doi.org/10.1108/ARJ-08-2013-0055.

Tahat, Y., Mardini, G. H., \& Power, D. M. (2017). Factors affecting financial instruments disclosure in emerging economies: The case of Jordan. Afro-Asian Journal of Finance and Accounting, 7(3). https://doi.org/10.1504/AAJFA.2017.085546.

Tauringana, V., \& Chithambo, L. (2016). Determinants of risk disclosure compliance in Malawi: A mixed-method approach. Journal of Accounting in Emerging Economies, 6(2), 111-137. https://doi.org/10.1108/JAEE-03-2014-0015.

Tsalavoutas, I., Evans, L., \& Smith, M. (2010). Comparison of two methods for measuring compliance with IFRS mandatory disclosure requirements. Journal of Applied Accounting Research, 11(3), 
213-228.

Tsalavoutas, I. (2011). Transition to IFRS and compliance with mandatory disclosure requirements: What is the signal? Advances in Accounting, 27(2), 390-405. https://doi.org/10.1016/j.adiac.2011.08.006.

Tsalavoutas, I., Tsoligkas, F., \& Evans, L. (2018). Compliance with IFRS mandatory disclosure requirements: A structured literature review. Journal of International Accounting, Auditing and Taxation (forthcoming).

Tsegba, I. N., Semberfan, J., \& Tyokoso, G. M. (2017). Firm characteristics and compliance with International Financial Reporting Standards (IFRS) by listed financial services companies in Nigeria. Applied Finance and Accounting, 3(1), 83. https://doi.org/10.11114/afa.v3i1.2196.

Urquiza, F. B., Navarro, M. C. A., \& Trombetta, M. (2010). Disclosure theories and disclosure measures. Revista Espanola de Financiacion y Contabilidad, 39(147), 393-415. https://doi.org/10.1080/02102412.2010.10779686.

von Alberti-Alhtaybat, L., Hutaibat, K., \& Al-Htaybat, K. (2012). Mapping corporate disclosure theories. Journal of Financial Reporting and Accounting, 10(1), 73-94. https://doi.org/10.1108/19852511211237453.

Weber, R. P. (1990). Basic content analysis. $2^{\text {nd }}$ ed. Newbury Park, CA: SAGE. https://doi.org/10.2307/2289192. 


\section{Appendix 1}

The disclosure index of IFRS 7:

\begin{tabular}{|c|c|c|c|c|}
\hline No. & \multicolumn{2}{|c|}{ Reference } & Title & Score \\
\hline \multicolumn{4}{|c|}{$\begin{array}{l}\text { SIGNIFICANCE OF FINANCIAL INSTRUMENTS FOR FINANCIAL POSITION AND } \\
\text { PERFORMANCE }\end{array}$} & \\
\hline \multicolumn{5}{|c|}{ Statement of financial position } \\
\hline & & & Categories of financial assets and financial liabilities & \\
\hline & 8 & & $\begin{array}{l}\text { Carrying amounts of each of the following categories shall be disclosed either } \\
\text { in the statement of financial position or in the notes: }\end{array}$ & \\
\hline 1. & & (a) & Financial assets measured at fair value through profit or loss - designated & \\
\hline 2. & & (e)i & Financial liabilities at fair value through profit or loss - designated & \\
\hline 3. & & (e)ii & Financial liabilities at fair value through profit or loss - held for trading & \\
\hline 4. & & (f) & Financial assets measured at amortised cost & \\
\hline 5. & & (g) & Financial liabilities measured at amortised cost & \\
\hline 6. & & (h)i & Financial assets measured at fair value through other comprehensive income & \\
\hline \multirow[t]{2}{*}{7.} & & (h)ii & $\begin{array}{l}\text { Investments in equity instruments at fair value through other comprehensive } \\
\text { income - designated }\end{array}$ & \\
\hline & & & Reclassification & \\
\hline 8. & 12B & $(a, c)$ & Date and amount of reclassification & \\
\hline \multirow[t]{2}{*}{9.} & & (b) & $\begin{array}{l}\text { Qualitative description of the change its effect on the entity's financial } \\
\text { statements }\end{array}$ & \\
\hline & & & Offsetting financial assets and financial liabilities & \\
\hline \multirow[t]{2}{*}{10.} & $13 \mathrm{~A}$ & & Offsetting disclosures information for all recognised financial instruments & \\
\hline & & & Collateral & \\
\hline 11. & 14 & (a) & Financial assets pledged as collateral & \\
\hline \multirow[t]{2}{*}{12.} & & (b) & Terms and conditions relating to pledge & \\
\hline & & & Compound financial instruments with multiple embedded derivatives & \\
\hline \multirow[t]{2}{*}{13.} & 17 & & $\begin{array}{l}\text { Instrument that contains both a liability and an equity component the } \\
\text { instrument has multiple embedded derivatives }\end{array}$ & \\
\hline & & & Defaults and breaches & \\
\hline 14. & 18 & (a) & $\begin{array}{l}\text { Any defaults and breaches during the period of principal, interest, sinking } \\
\text { fund, or redemption terms of those loans payable }\end{array}$ & \\
\hline \multicolumn{4}{|c|}{$\begin{array}{l}\text { Statement of income: Items of income, expense, gains or losses - Other } \\
\text { comprehensive income }\end{array}$} & \\
\hline 15. & 20 & (a)i & $\begin{array}{l}\text { Net gains/losses on by classes of financial instruments at fair value } \\
\text { (designated or held for trading) }\end{array}$ & \\
\hline 16. & & (a)v,vi & $\begin{array}{l}\text { Net gains/losses on financial liabilities and financial assets measured at } \\
\text { amortised cost }\end{array}$ & \\
\hline 17. & & (b) & Total interest revenue and total interest expense & \\
\hline 18. & & (c) & Fee income and expense & \\
\hline
\end{tabular}




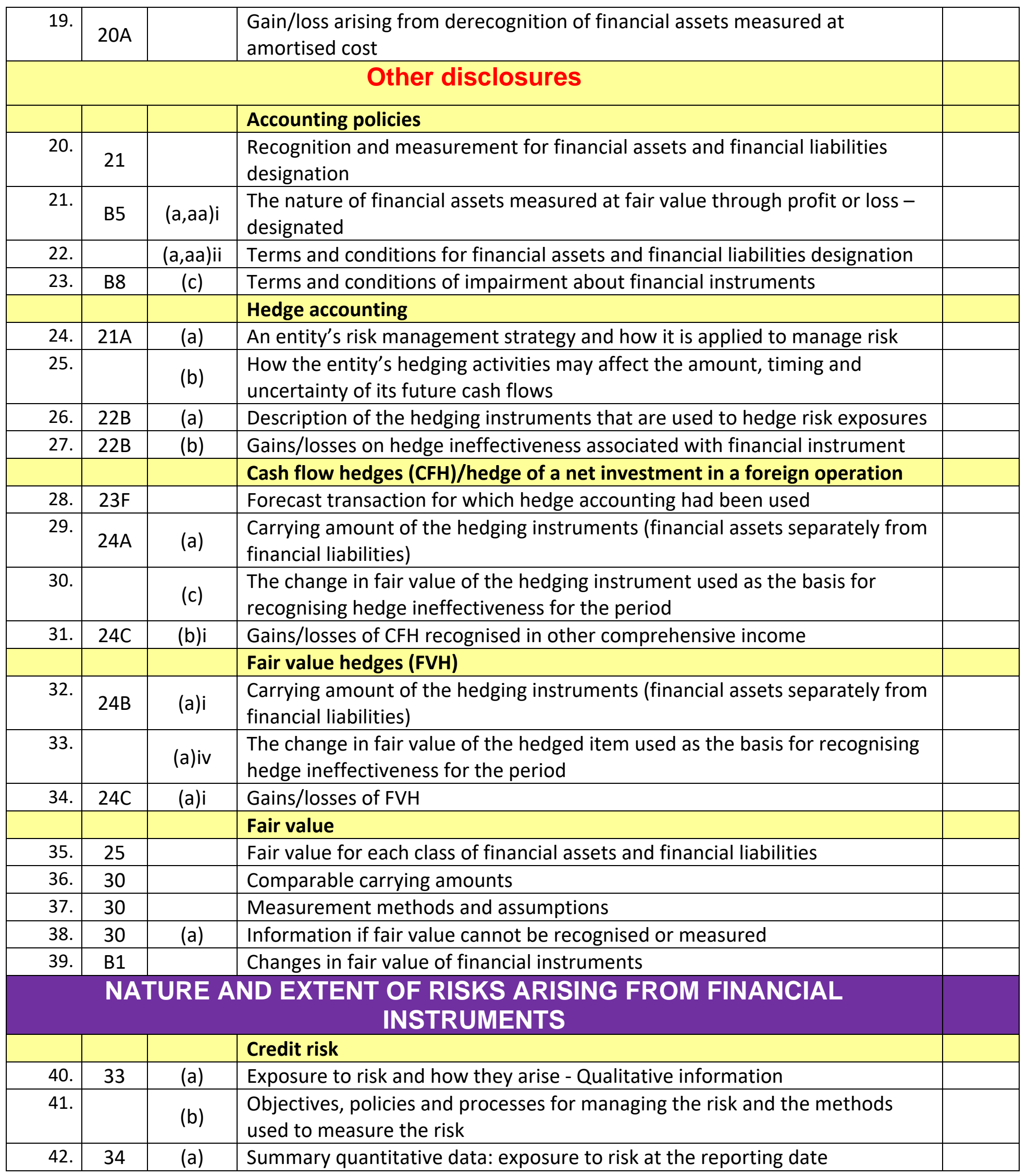




\begin{tabular}{|c|c|c|c|}
\hline 43. & & (c) & $\begin{array}{l}\text { Concentrations of credit risk if not apparent from summary quantitative data } \\
\text { and sensitivity analysis }\end{array}$ \\
\hline 44. & 36 & (a) & $\begin{array}{l}\text { Amount of maximum exposure to credit risk (before deducting value } \\
\text { collateral) }\end{array}$ \\
\hline 45. & & (b) & $\begin{array}{l}\text { A description of collateral held as security and other credit enhancements } \\
\text { security and credit-impaired at the reporting date }\end{array}$ \\
\hline 46. & $35 \mathrm{M}$ & & $\begin{array}{l}\text { A summary of credit risk rating grades that shows credit quality of financial } \\
\text { instruments by asset class }\end{array}$ \\
\hline 47. & $35 \mathrm{H}$ & & Allowance account for credit losses - qualitative information \\
\hline 48. & & & $\begin{array}{l}\text { Allowance account for credit losses - quantitative information (changes in the } \\
\text { loss allowance during the period }\end{array}$ \\
\hline 49. & $35 \mathrm{H}$ & (b)i,ii & $\begin{array}{l}\text { Allowance account for credit losses - information about financial instruments } \\
\text { for which credit-impaired/not credit-impaired }\end{array}$ \\
\hline 50. & 38 & (a) & $\begin{array}{l}\text { Nature and carrying amount of assets obtained by taking possession of } \\
\text { collateral it holds as security or calling on other credit enhancements }\end{array}$ \\
\hline \multirow[t]{2}{*}{51.} & & (b) & $\begin{array}{l}\text { Policies for disposing assets or use of it in its operations when the assets are } \\
\text { not readily convertible into cash }\end{array}$ \\
\hline & & & Liquidity risk \\
\hline 52. & 33 & (a) & Exposure to risk and how they arise - Qualitative information \\
\hline 53. & & (b) & $\begin{array}{l}\text { Objectives, policies and processes for managing the risk and the methods } \\
\text { used to measure the risk }\end{array}$ \\
\hline \multirow[t]{2}{*}{54.} & 39 & $(a, b)$ & $\begin{array}{l}\text { Maturity analysis for financial liabilities that show the remaining contractual } \\
\text { maturities }\end{array}$ \\
\hline & & & Market risk - interest rate risk \\
\hline 55. & 33 & (a) & Exposure to risk and how they arise - Qualitative information \\
\hline 56. & & (b) & $\begin{array}{l}\text { Objectives, policies and processes for managing the risk and the methods } \\
\text { used to measure the risk }\end{array}$ \\
\hline 57. & 34 & (a) & Summary quantitative data: exposure to risk at the reporting date \\
\hline 58. & & (c) & $\begin{array}{l}\text { Concentrations of interest rate risk if not apparent from summary } \\
\text { quantitative data and sensitivity analysis }\end{array}$ \\
\hline 59. & 40 & (a) & $\begin{array}{l}\text { Interest rate sensitivity analysis showing how profit or loss and equity would } \\
\text { have been affected by changes in the relevant risk variable that were } \\
\text { reasonably possible at that date }\end{array}$ \\
\hline \multirow[t]{2}{*}{60.} & & (b) & Methods and assumptions used in preparing the sensitivity analysis \\
\hline & & & Market risk - currency risk \\
\hline 61. & 33 & (a) & Exposure to risk and how they arise - Qualitative information \\
\hline 62. & & (b) & $\begin{array}{l}\text { Objectives, policies and processes for managing the risk and the methods } \\
\text { used to measure the risk }\end{array}$ \\
\hline 63. & 34 & (a) & Summary quantitative data: exposure to risk at the reporting date \\
\hline 64. & & (c) & $\begin{array}{l}\text { Concentrations of currency risk if not apparent from summary quantitative } \\
\text { data and sensitivity analysis }\end{array}$ \\
\hline
\end{tabular}




\begin{tabular}{|c|c|c|c|}
\hline 65. & 40 & (a) & $\begin{array}{l}\text { Currency risk sensitivity analysis showing how profit or loss and equity would } \\
\text { have been affected by changes in the relevant risk variable that were } \\
\text { reasonably possible at that date }\end{array}$ \\
\hline \multirow[t]{2}{*}{66.} & & (b) & Methods and assumptions used in preparing the sensitivity analysis \\
\hline & & & Market risk - other price risk \\
\hline 67. & 33 & (a) & Exposure to risk and how they arise - Qualitative information \\
\hline 68. & & (b) & $\begin{array}{l}\text { Objectives, policies and processes for managing the risk and the methods } \\
\text { used to measure the risk }\end{array}$ \\
\hline 69. & 34 & (a) & Summary quantitative data: exposure to risk at the reporting date \\
\hline 70. & & (c) & $\begin{array}{l}\text { Concentrations of other price risk if not apparent from summary quantitative } \\
\text { data and sensitivity analysis }\end{array}$ \\
\hline 71. & 40 & (a) & $\begin{array}{l}\text { Other price risk sensitivity analysis showing how profit or loss and equity } \\
\text { would have been affected by changes in the relevant risk variable that were } \\
\text { reasonably possible at that date }\end{array}$ \\
\hline 72. & & (b) & Methods and assumptions used in preparing the sensitivity analysis \\
\hline & & & TRANSFERS OF FINANCIAL ASSETS \\
\hline & $42 \mathrm{~A}$ & & $\begin{array}{l}\text { An entity shall provide the required disclosures for all transferred financial } \\
\text { assets that are derecognition/not derecognised: }\end{array}$ \\
\hline 73. & 42D & (a) & The nature of the transferred financial assets \\
\hline 74. & & $(b, c)$ & $\begin{array}{l}\text { The nature of the risks, rewards and liabilities associated with the transferred } \\
\text { financial assets }\end{array}$ \\
\hline 75. & & (e) & The carrying amounts of the transferred assets and the associated liabilities \\
\hline 76. & $42 \mathrm{G}$ & (a) & The gain or loss recognised at the date of transfer of the assets \\
\hline
\end{tabular}

